\title{
THE NEW ROLE OF ULAMA IN NIGERIA Focus on the Post 1999 Democratic Dispensation
}

\author{
Mukhtar Umar Bunza
}

Usmanu Danfodiyo University, Sokoto, Nigeria

email:mbunza@hotmail.com

\section{Abstract}

Nigeria is a country with a centuries' long tradition of Islamic revivalism and activism. It was the impact of the activities of the $17^{\text {th }}$ century scholars of Nigeria that culminated in the success of the $19^{\text {th }}$ century tajdeed movement that brought about the emergence of the muslim caliphate of Sokoto. British imperialism brought an end to the caliphate in the beginning of the $20^{\text {th }}$ century, the circumstances of which have been consistently challenged mainly by the ulama and their followers ever since. Some contemporary scholars such as Shaikh Abubakar Mabmud Gummi, former Grand Qadi of Northern Nigeria, contributed significantly in the new dimension to the roles of muslim scholars in the government. Since 1999 muslim scholars have taken on new roles in the administration of states, serving as commissioners for newly established ministries for Religious Affairs, as special advisers, or directors of commissions like Hisbah, Hajj, Masjid, Moon Sighting, and other related government bodies, with full salaries and other benefits unlike ever before in the Nigerian system. This new role of ulama and its impacts in the governance of the contemporary Nigeria is what this paper intends to investigate and expound. Nigeria merupakan sebuah negara dengan tradisi revivalisme dan aktivisme Islam selama berabad-abad. Hal itu terkait dengan upaya para ulama Nigeria abad ke-17 yang berpuncak pada keberhasilan gerakan tajdidpada abad 19 dengan munculnya kekhalifahan muslim dari Sokoto. Imperialisme Inggris mengakbiri kekhalifahan ini pada awal abad ke-20, yang terus dilawan oleh terutama para ulama secara konsisten. Beberapa ulama kontemporer seperti Syaikh Abubakar Mabmud Gummi, mantan Grand Qadi Nigeria Utara, memberikan kontribusi signifikan dalam membentuk dimensi baru peran 
ulama dalam pemerintahan Nigeria modern. Sejak, tahun 1999 para ulama telah mengambil peran baru dalam pemerintahan, sebagai pegawai Kementerian Agama yang baru didirikan, sebagai penasibat abli, atau direktur komisi seperti Hisbah, Haji, Masjid, Rukyah Hilal, dan badan-badan pemerintah terkait lainnya, dengan gaji penuh. Peran baru dari ulama dan pengarubnya dalam pemerintahan Nigeria kontemporer inilah yang menjadi fokus tulisan ini.]

Keywords: Nigeria, ulama, muslim countries

\section{A. An Overview on the Roles of Ulama in Muslim Societies}

The nature of the religion of Islam on the basis of its creed, the practice and interpersonal and interstate relations mean that it is strictly based on laid down rules and regulations. Every aspect of the religious practice must have approval --whether haläl (permissible) or harām (prohibited), and the ways and manner of its practice well prescribed and enshrined. That is what makes Islam heavily dependent on its sources of law, i.e. the Quran, the Sunnah, and other literature on jurisprudence and its general norms and practices. Thus, followers are in constant need of a mediator who explains and elucidates the tenets in conformity with what Allah the most High ordained.

That was the reason why the holy prophet was sent to explain and teach people the message. The Quran (15:1-3) makes it clear as explained by Ibn Kathīr:

This is a Book that We have revealed to you, O Muhammad. This Book is the Glorious Quran, the most honored Book, that Allah sent down from heaven to the most honored Messenger of Allah sent to all the people of the earth, Arabs and non-Arabs alike in order that you might lead mankind out of darkness into light. We sent you, O Muhammad, this Book in order that you might lead mankind away from misguidance and crookedness to guidance and the right way (15:1-3).

It was the philosophy and wisdom behind explaining the plain truth and teaching of the religion that made the issue of communication and language useful. Prophets and messengers who spoke the language of their people were sent to their nations and communities so that those communities would clearly understand the Divine revelation from mortals like themselves. Ibn Kathīr further explains the wisdom of verse 14:4,

"And We sent not a Messenger except with the language of his people, 
in order that he might make (the Message) clear for them. Allah is Kind and Compassionate with His creation, sending Messengers to them from among them and speaking their language, so that they are able to understand the Message that the Messengers were sent with".

In Islam, Muhammad (SAW) is the last messenger and prophet till the end of time. That special nature of Islam makes ulama, the scholars, responsible for the task of explaining the meaning and essence of the Islamic tenets to Muslims in the language and the form that they understand. Thus, as the Prophet was the embodiment of faith and piety so also the ulama, as they too are constantly asked about religious and personal issues. As in the Quran, yas'alünaka (they ask you), yastaftünaka (they seek your legal verdict), etc abound, indicating the exalted position of the Prophet to issue legal opinion and guide the people. In the same tradition, as the ulama succeed the Prophet, they were confirmed with that responsibility by the Quran, where Muslims were directed in the absence of the Prophet to direct their questions to the ulama.

In the beginning they were identified as the custodians of faith and piety with the task of removing any doubt from the minds of followers, thus confirming that: "It is only those who have knowledge among His servants that fear Allah". Meaning, only those who have knowledge truly fear Him as He should be feared, because the more they know about the Almighty, All-Powerful, All-Knowing, Who has the most perfect attributes and is described with the most beautiful Names, the more they will fear Him. ${ }^{1}$ That gives a scholar another quality of authority to pass verdict on behalf of the Lawgiver and His Prophet whenever consulted, and people are on the other hand directed not to act on matters of religion without guidance, they should therefore consult the ulama in the Quranic perspectives as follows: “...Ask the people of knowledge (ulama) if you know not...". The role and importance of the ulama class of people in Muslim societies is worthy of study and articulation across disciplines for clear understanding of the dynamics of Muslim actions and reactions in contemporary world affairs.

In the opinion Muhammad Qasim Zaman, that was not an exaggeration of the complex and changing roles of the ulama. Thus;

The 'new religious intellectuals' emerging in the Muslim public sphere undoubtedly merit close attention, and the contemporary Islamist movement continues to be in much need of sober analyses. The emphasis

${ }^{1}$ See Commentary of Chapter 35: 28 in Tafsīr Ibn Kathīr of the Glorious Quran. 
on relatively new and emerging intellectuals and activists should not, however, obscure the significance of a community of religious scholars that has existed in Muslim societies, the ulama --their transformations, their discourses, and their religio-political activism-- can, indeed, only be neglected at the cost of ignoring or misunderstanding crucial facets of contemporary Islam and Muslim politics. $^{2}$

Therefore, the role of ulama in Muslim societies transcends from spiritual, to temporal in the form of economic, political, social and even some personal issues, as Muslims are generally requested to fashion their lives entirety in line with teachings and laws of Islam. It is also the fundamental responsibility of scholars to protect the religion from corruption, defend it from aggression and protect its sanctity and purity. Ulama should also serve as protectors of justice and uphold it, and protect and support the weak in the face of aggression from the powerful whether government, group or an individual.

In order to effectively discharge that responsibility, they should be enlightened not only about the literature but also contemporary events and occurrences, and should have knowledge and information on other parts of the world in terms of development, military prowess, economic opportunities, as well as religious advancement for them to be able to effectively strategize for the Muslim ummah, and not be left behind. The ulama and or their ideas move from one area to another discharging their responsibilities as luminaries of the society. That was exactly the Nigerian experience of this category of people. ${ }^{3}$

That was the reason why Shehu Usmanu Danfodiyo, the founder of the $19^{\text {th }}$ century Islamic caliphate in Nigeria directs that:

Busy yourselves, then, oh my brethren by reading the literary works (written) by scholars of your time. This is because they know those things that are important to your time and situation. It has become part of their (scholars) effort to give details of those things (that are important to your situation but) given briefly in books of previous scholars. Hence the works of each of generation serve as additional explanation to the literary works of those who preceded them. For this reason, each scholar (in every period) exerted effort and busied himself with authorship on his

${ }^{2}$ Muhammad Qasim Zaman, The Ulama in Contemporary Islam: Custodians of Change (New York: Princeton University Press, 2007), p. 1.

3 Mukhtar Umar Bunza, "Migration and Itinerancy among the Ulama'a in West Africa: The Making of Trans-National Muslim Intelligentsia in Nigeria", in Religion et Migration, ed. by E. Ross, F. Harrak \& S. Anegay (Rabbat: Institute des Etudes Africaines, 2012), pp. 65-80. 
own, notwithstanding, that all that which could satisfy people's need in matters of religion were available in the books of the scholars before him (but to update Muslims and keep them informed of the contemporary developments). ${ }^{4}$

The role of the ulama class since the time of the companions, those who followed them, to the period of the four imams of the Schools of Thought (Imam Malik, Shafii, Ahmad bin Hanbal and Abu Hanifa), shows the singular contribution of ulama in debating, arguing and finding solutions to the emerging problems of the Muslims. Jabarti shows the importance of the ulama class among the Muslim populace in the following:

In the first category were the prophets who were sent to reveal God's message to mankind and to show the world the path of righteousness. In the second category were the ulama who are the heirs and the successors of the prophets, 'the depositories of truth in this world and the elite of mankind'. ${ }^{5}$

The same tradition continues from generation to generation; each generation of ulama addresses issues that were topical and relevant to the need, challenges, and aspirations of the Muslims in the period in question.

Shireen rightly observes that the Muslim ummah and by implication the ulama have faced very serious challenges in the interpretation and practice of the religion of Islam since the nineteenth century when virtually all the Muslim territories were colonized by one Christian European power or another. In his opinion, the challenge resulted in variations in approach and methodology among the ulama reformers in Muslim societies, thus:

Since the nineteenth century, with certain variations, these two different conceptions of reform and renewal have coexisted and competed in the Muslim world. However, the main motivation and the ultimate goal of all renewers and reformers, despite differences of opinion regarding what constitutes reform, the essentials of Islam, and the best methodology for the interpretation of major Islamic sources, have always been the following: (1) return to the basic sources of Islam, namely the Quran and the sumna; (2) restoration of Muslims' faith and morality; (3) intellectual, economic, and political revitalization of the Muslim world;

\footnotetext{
${ }^{4}$ Shehu Usmanu Danfodiyo, Najm al-Ikhwān Yahtadūnā bi-Hìbbi Idhnillāh fì Umūr al-Zamān (Cairo), pp. 3-4.

5 Jeffrey Charles Burke, "The Role of Ulama' during the French Rule of Egypt, 1798-1801”, Dissertation (Canada: McGill University, 1992), p. 2. 
(4) strengthening the Islamic community and defending it against internal and external enemies; and (5) ensuring Islam's continued relevance to Muslims' lives in all its dimensions. ${ }^{6}$

The philosophy of Sokoto Ulama (the triumvirate) on the role of a scholar prescribed that, in all the efforts a scholar makes for the Muslim ummah, especially on issues regarding emerging new cases and the question of maslahah, the common good of the ummah should be made a top priority and not be subjected to backwardness as a result of his fatwa-legal opinion. In deciding a legal verdict for any new or emerging problem ulama must be aware and conscious of culture, tradition, norms, psychology as well as the current world situation in determining the legal judgment for Muslims. ${ }^{7}$ The influence of ulama, as well as the power of their voices in shaping and re-shaping the direction and reaction of Muslim societies has not faded in spite of political, economic and technological transformations. Thus, a brief survey of such contributions in different facets of human endeavor in spite of changing time and circumstances gives a solid foundation for understanding the engagement of the Muslim world in challenging contemporary situations.

In the Arab world for instance, since the eighteenth century when the pact of politico-religious reform movement was reached between Muhammad bin Abdulwahhab and Abdulaziz which resulted to creation of modern Saudi Arabia, the ulama especially Sheikh Ibn Abdulwahhab have been part and parcel of governance and decision making in Saudi Arabia. The role they play in religious and political matters are indubitable. In fact a segment of ulama are considered as partners in the administration of the state which their forebears strove to establish. With the exception of a few who are viewed as radical and uncompromising, the ulama are to a certain extent strong stakeholders in state affairs; as the Sheikh Ibn Abdulwahhab was the real power behind the throne, so, today, the ulama stand to legitimize the government in Saudi Arabia. ${ }^{8}$

In other parts of the Arab world, notably Jordan and Syria as Jawad Qureshi argued, the role of ulama is considerable not only in the

${ }^{6}$ Shireen T. Hunter (ed.), Reformists Voices of Islam: Mediating Islam and Modernity (New York: M.E. Sharpe, 2009), p. 5.

7 See details in Abdullahi Alhaji Shehu Sokoto, "Al-Ulama: Towards a Conceptual Definition", in The Impact of the Ulama in the Central Al-Sudan (Nigeria: Centre for Trans-Saharan Studies-University of Maiduguri, 1990), pp. 1-31.

8 See details in Jean Jacques Waardenburg, Islam: Historical, Social, and Political Perspectives (Berlin: Walter De Gruyter, 2002), pp. 229-41. 
religious sphere but in determining the direction of the political landscape. According to Qureshi, the voices of ulama have been as popular as that of the political class. The influence of Shaikh Said Ramadan al-Bouti since the publication of his book Naqd Awhäm al-Mãdiya al-Jadaliya (Critique of the Delusions of Dialectical Materialism), which brought him closer to late Hafiz Asad of Syria, and al-Isläh al-Jadhri (Fundamental Reform) in which he articulates issues regarding the development and performance of office holders in Syria made the government concerned about the views of scholars in modern Syria. That also led to a meeting between Bashar Asad and protesters at the beginning of the Arab Spring reform in the presence of Shaikh Bouti, in which he said, 'everything that might occur to the minds of those that are raising banners was laid out and discussed'? Qureshi also analyses the impact of Shaikh Usama al-Rifafi's sermon in Damascus, Syria, especially the lecture series of Masuliyun directed to the President and the people at the helm of affairs as constituting a strong force in checking the excesses of administration. Similarly, the influence of Shaikh Badr al-Din Hassoun, Shaikh Ahmad Kuftaro, Shaikh Wahbe Zuhayle, Mustafa al-Khinn, Mustafa al-Bugha, Shaikh Kuraym Rajih, Shaikh Muhammad al-Yaqoubi and a host of others confirms the power of Ulama even in a secular, Baathist society such as Syria. ${ }^{10}$

The same scenario of persistence could be found in the role of ulama in Egypt; Egypt like other Arab countries has been under the political control of monarchs, military dictators and civilians who consistently muffled the voice of Islam and its relevance to public life through secularism and waxing and tuning to the tone of the European imperialists. For centuries ulama in Egypt have been in continuous engagement on how to salvage Islam in the face of internal rejecters and external threats. Several studies were conducted on this, for instance, Shadaab Rahemtulla's study, "Reconceptualizing the Contemporary Ulama al-Azhar, Lay Islam, and Egyptian State in the Late $20^{\text {th }}$ Century", 11 Jeffrey Charles Burke's study entitled, "The Role of Ulama during the French Rule of Egypt, 1798-1801", ${ }^{12}$ Baer Gabriel's broader assessment of the role of ulama with some specific focus on Egypt in his book, The

9 Jawad Qureshi, The Discourses of the Damascene Sunni Ulama During the 2011 Revolution (Scotland: University of St. Andrews Centre for Syrian Studies, 2012), p. 63.

10 Ibid., pp. 64-84.

11 Shadaab H. Rahemtulla, "Reconceptualizing the Contemporary Ulama alAzhar, Lay Islam, and Egyptian State in the Late 20th Century", M.A. Thesis (Canada: Simon Fraser University, 2005).

12 Burke, "The Role of the 'Ulamā'." 
Ulama in Modern History, ${ }^{13}$ Afaf Lutfi's remarkable contribution to this discourse on ulama in Egypt, with the "Role of Ulama in Egypt during the Early Nineteenth Century", "A Socio-Economic Sketch of the Ulama in the Eighteenth Century", "The Ulama in Cairo...", and "The Wealth of the Ulama...". ${ }^{14}$ In these and other studies about ulama in Egypt, a simplistic conclusion can be derived from the following statement:

The strong ruler thus used the ulama either to legitimatize his actions vis a vis the community, or to help him rule the people, for in a society dominated by religion and tradition, the moral influence of the ulama was great, and their right to participate in matters of government recognized. ${ }^{15}$

The influence of some ulama in modern Egypt such as Muhammad Abduh, Rashid Rida, Kishk, Mahallawe, Yusuf Qaradawi, Hassan Albanna, Sayyid Qutb, Muhammad Mitwalli Sha'arawi, and the Azhar Shaikhs contributed to shaping public opinion on spiritual as well as mundane issues. No system or government can survive in Egypt without collaborating, silencing or striking a deal or pact with the ulama to ensure the endorsement of their strong voices that echo mostly on behalf of the voiceless masses.

Jacqueline Brinton submits on the power ulama in Egypt because they:

... continue to use the medium of preaching as a means of instructing the public. Egypt Ulama preachers still interpret the Qur'an and hadith to bring forth new responses, ones attuned to their particular environment. They still function as intermediaries in order to present a full or accurate picture of contemporary religion. The ulama in Egypt still lead the populace because they have been able to reaffirm their status, thus protecting their vocation into the future. ${ }^{16}$

13 Published by The Israel Oriental Society, Jerusalem, 1971. Other relevant works on the subject include: Daniel Crecelius, "Non-ideological Response of the Egyptian Ulama' to Modernization", in Scholars, Saints, and Sufis: Muslim Religious Institutions in the Middle East since 1500, ed. by Nikki R. Keddie (Los Angeles: University of California Press, 1972); Yvonne Yazbeck Haddad, "Muhammad Abduh: Pioneer of Islamic Reform”, in Pioneers of Islamic Revival, ed. by 'Alī Rāhnamā (London: Zed Books, 1994), and others.

${ }^{14}$ See Afaf Lutfi al-Sayyid Marsot, "The Role of the 'Ulama' in Egypt, Early Nineteenth Century", in Political and Social Change in Modern Egypt, ed. by P.M. Holt (Oxford: Oxford University Press, 1968); Crecelius, "Non-ideological Response."

${ }_{15}$ Burke, "The Role of the 'Ulamā"”, p. 10.

${ }^{16}$ Jacquelene Brinton, "Preaching and the Epistemological Enforcement of 'Ulamā' Authority: the Sermons of Muhammad Mitwallī Sha'rāwī”, Intellectual Discourse, vol. 19, no. 1 (2011), pp. 91-9. 
That was why some ulama who critiqued governments and refused to compromise were killed, jailed or systematically silenced in order for such regimes to maintain power. Hardly any program or government policy could succeed without having the backing and support of this class of people who contact the populace at various fora, more often at mosques, madrasas and preaching sessions through which they spread their views and ideas. ${ }^{17}$

In Iran even before the 1979 Islamic Revolution, the ulama had glaringly been a power to reckon with in terms of political control and decision-making in the Shiite Iranian societies. However, the emergence of Imam Khomeini on the political scene in Iran proved beyond doubt the capacity and capability of ulama to institute political change in the modern world; a phenomenon almost inconceivable before. According to Kalim Siddqui, the major contribution of Imam Khomeini was in breaking the old tradition of withdrawal of ulama from power, and extending his ijtihad in the political sphere, through formulating a government and control of political authority. The role of such politically influential scholars, such as Ayatullah Khomeini, Taleqani, Shariati, Murtada Muttahari, Shaikh Naimi, Fadlullah and a host of others in shaping the political landscape of modern Iran has been conspicuous. Not only did these scholars bring the ulama into affairs of government but they also contributed significantly to contemporary discourse on political theory, political philosophy and public administration. Ayatullah Taleqani developed the idea "that universal sovereignty belongs to God. Second, at the earthly level, this divine authority is vested in the Prophet and the imams, and, in their absence, in the just ulema and just believers". ${ }^{18}$ They expounded on Islam and Constitutional Government, on issues on constitutionalism, the Iranian Islamic Movement and Islamic Government in the modern world. ${ }^{19}$

The shapers of Muslim minds and political actors among Muslim scholars in the Indian sub-continent such as Abul' Al aMaududi, Fazlur Rahman, Abul Hassan Ali Al-Nadawi, Khurshid Ahmad and a number of ulama organizations and movements with political and religious tinge

${ }^{17}$ Citing Marsot, "The Role of the 'Ulama"'; Burke, "The Role of the 'Ulamā", p. 10.

${ }^{18}$ See "Imam Khomeini, "Ijtihad and the Role of Ulama", Crescent Magazine, International Nensmagazine of the Islamic Movement (29/7), http://www.crescent-online. net/2009/08/imam-khomeini-ijtihad-and-the-role-of-ulama-1649-articles.html, accessed 22 Aug 2014.

${ }^{19}$ Hunter (ed.), Reformist Voices of Islam. 
also played very remarkable roles in their societies. The major challenge faced by the ulama of this region of the modern world was situating Islam as a religion and culture in the life of the people which was radically altered through the British colonization. The scholars tried to maintain the provision of Islamic as well western education and continued to struggle for the relevance of religion in state matters. It was the fruit of such persistent effort that resulted to the declaration of Islamic State of Pakistan by President Ziaul Haqq. Qasim Zaman, Esposito and Donohue shed some light on this. ${ }^{20}$ That declaration was similar in purpose and context to the declaration of Islamic Sharia'h in Nigeria after 1999 by about eleven democratically elected governors.

The role and influence of ulama among the Muslim nations of Malaysia and Indonesia are worthy of our review in this regard. In Malaysia for instance, the deep-rootedness of Islam in the region as well as the power of ulama since the pre-British period with the Sultan, and also after the independence in 1957 with elected political leaders is a confirmation of the strong support and backing enjoyed by the ulama. Abdul Kadir and Mohammad Nor identified that: 'The ulama was the most influential group in the community in Malaysia due to their understanding of the revealed knowledge. The ulama were considered as advisors to the Sultan, and served in significant positions in the current political dispensation. In alliance and collaboration with the state apparatus, the ulama have become formidable pillars in uplifting the state and Islamic education in Malaysia. Some influential scholars of pre-independence Malaysia whose impacts are still felt and upheld by a number of contemporary ulama include Tuan Haj Muhammad, Shaikh Abdullah Maghribi, Sheikh Abdullah Fahim, and Haj Zubair Shaikh Ahmad among others. ${ }^{21}$

The ulama in Indonesia have historically held traditional roles of spiritual and temporal power and influence. An Indonesian anthropologist concludes that:

The Indonesian term ulama is used to denote both religious scholars

20 Zaman, The Ulama in Contemporary Islam, pp. 251-272.

${ }^{21}$ See Nor Adina Abdul Kadir and Mohd Roslan Mohd Nor, "The Role of Ulama in Reconstructing of Religious Education in Malaysia during Early 20th Century", Middle-East Journal of Scientific Research, vol. 11, no. 9 (2012), pp. 1257-65; Farish A. Noor, Yoginder Sikand, and Martin van Bruinessen (eds.), The Madrasa in Asia: Political Activism and Transnational Linkages (Amsterdam: Amsterdam University Press, 2009); M. Ismail, Ulama Silam dalam Kenangan (Malaysia: Bangi University, 1993). 
who have thorough knowledge of Islam and socio-religious leaders who occupy important and strategic position. The ulama, namely - men of religious learning and prestige play important social, political, cultural, and religious roles in the history and development of Muslim society in Indonesia. In the history, the ulama led their community to fight against colonial authorities so that they could free the country from colonialism and Indonesia obtained its independence on August 17, 1945. In the independence era the country still owed the role of the ulama in succeeding its development programs in various fields such as education, social, politics, economy, religion, and culture. There is no single development program that is not supported by the ulama. Here, we witness the diverse roles of ulama, going beyond the traditional domain of the religious sphere into rural areas (emphasis mine). ${ }^{22}$

In Indonesia, the increasing influence of Majlis Ulama, Nabdatul Ulama or even the so-called radicals Majlis Mujabibidin Indonesia, Laskar Jihad, Front Pembela Islam, Partai Keadilan Sejabtera apart from ensuring the survival of Islam in modern state system, the more radical groups are more focused on implementing Shariah law. The challenging roles performed by these ulama bodies are major indicators that the scholars enjoy considerable respect and authority both among the political elites and the general population. Yusny Saby suggests that in Aceh (Sumatra) the ulama play a vital role in 'the improvement of education, fighting against social problems, and encouraging political participation to strengthen the power of ulama in the region even among secular politicians. ${ }^{23}$ Related to this, was the contribution of ulama in Singapore in advancing the course of Islam and also making the case for the recognition of Islamic education by the government in the country. ${ }^{24}$

The above brief survey on the role of ulama in Muslim societies provides a clue to understanding the universal phenomenon with regard to the importance and influences of this class of people as not only limited to the Nigerian situation but in what may be considered almost

${ }^{22}$ Zulkifli, "The Ulama, Religious Authority and Recognition in Indonesia", presented at the Annual Conference on Islamic Studies X (Banjarmasin, 1 Nov 2010). For a general discussin on the Intitution of Ulama' in Indonesia, see Azyumardi Azra, Islam in the Indonesian World: An Account of Institutional Formation (Jakarta: Mizan Pustaka, 2006).

${ }^{23}$ Yusny Saby, Islam and Social Change: The Role of the Ulama in Acebnese Society (Malaysia: Universiti Kebangsaan Malaysia, 2005), pp. 2-3.

${ }^{24}$ Kerstin Steiner, Madrasah in Singapore: Tradition and Modernity in Religious Education, SSRN Scholarly Paper, no. ID 2342393 (New York: Social Science Research Network, 2011), pp. 41-71. 
a universal tradition among Muslims of all geographical spaces, and historical orientations and experiences.

\section{B. The $19^{\text {th }}$ Century Caliphate and the Transfer of Political Power to the Ulama in Nigeria}

Prior to the nineteenth century Jihad, led by Shehu Usmanu Danfodiyo in the Muslim regions of modern Nigeria, the roles of the ulama were more or less advisory and supportive of the traditional institutions under the Sarakuna (Kings) (sing. Sarki, king). They served in various capacities in the courts of these rulers for centuries as scribes, accountants, diplomats, and with other literary responsibilities. In the 1460s, especially with the aid of Shaikh Muhammad ibn Abdulkarim al-Maghili of Algeria, the political function of the ulama became more pronounced.

However, in conflict with the religious premise of justice and equity for all, through corruption and abandonment of their responsibilities as custodians of the truth and helpers and supporters of the weak, the credibility of the ulama was shattered. Consequently, a clique of young scholars, from twenty to thirty years of age, instigated an intellectual resistance movement which metamorphosised into a jihad which broke out in 1804.

The contention of those ulama was that there was widespread corruption and injustice in various segments and systems of society. Further, the ulama instead of fighting against societies ills justified and collaborated with kings to perpetrate such evils. Thus, in a publication which the leader of the movement, Danfodiyo, (referred to as Shehu interchangeably in this paper), wrote his manifesto entitled Kitab alFarqbaynawilayatabl al-Imani waabl-Al-Kufr-The Book of Criterion between the government of the Believers and that of the Unbelievers, in which he made about twenty nine charges against the existing governments and administrations in the $19^{\text {th }}$ century Nigerian areas. Each of these charges according to Danfodiyo warrants that Kings be relieved of their powers if they refuse to reform for the better or continue to act unjustly, as outlined in the Shari'ah. According to Danfodiyo:

One of the ways of their government (in Hausaland) is succession to the emirate by hereditary right (monarchy) and by force (military take-over) to the exclusion of consultation. And one of the ways of their government is the building of their sovereignty upon three things: the person, their honor, and their possessions; and whomsoever they wish to kill or exile 
or violate his honor or devour his wealth they do so in pursuit of their lusts, without any right in the Shari'ah. ${ }^{25}$

Shehu viewed the ulama who refused to support the truth against falsehood as betrayers of the trust and divine responsibility shouldered on them. Shehu categorically charged that class of ulama with treachery and the hindering of the progress of the way of Allah in several treatises such as Wathiqat al-Ikhwan, Nur al-Bab, Kiatb Wujub al-Hijrah al-Ilbad, Najm a-Ikhwan among others. Shehu branded such scholars as 'more dangerous than the devil, and their position in the society was no better than a rock in the sea, which neither drinks water nor allows anybody to drink'. Removing their influence in governance and the society entirely was, in the opinion of the Shehu, the catalyst to attaining a viable political system. ${ }^{26}$ The Shehu's contention against the ulama al-Su'i-venal scholars - as expressed in Wathiqat al-Ikhwan was synonymous with that of Sidi al-Mukhtar al-Kunti's description of such ulama in the following:

They (the venal ulama) included those who had knowledge but failed to put it into practice; those who presented an appearance of compliance with the outward religious duties, but had not eliminated characteristics such as vanity, hypocrisy, ambition, desire for political office and high rank; those who presumed that they had the exclusive right to guide the common people and yet entered into unholy alliance with the (corrupt political leaders) sultans, thus encouraging the sultans' (leaders') oppression of the people; those who engaged in jibad but only to obtain fame and wealth; and those scholars who used false methods, such as music, to lure people into spiritual practices. The danger of those scholars, the Sidi said, could be seen from the hadith of the Prophet (Allah bless him and grant him peace): 'I fear for my umma after me more from ulama al-su' (venal scholars) than from the Dajjal, and when asked who these were, he replied that they were ulama al-alsina, the ulama of the tongue'. ${ }^{27}$

Instead of reforming their practices towards a right and just system, the ulama al-Su' acted in collaboration with and with the obvious support

25 See Shehu Usmanu Danfodiyo, Kitab al-Farq, trans. by Mervyn Hiskett, (Sokoto: Bi-Centernary, 2004), pp. 2-3.

${ }^{26}$ Shehu made this statement in this Wathiqat al-Ikhwain, however discussion on the issues could be found in Yusufu Abba, "The 1804 Jihad in Hausaland as a Revolution", in Studies in the History of the Sokoto Caliphate: The Sokoto Seminar Papers, ed. by Yusufu Bala Usman (Nigeria: Dept. of History, Ahmadu Bello University, 1979), pp. 20-3. The chapter is generally good for understanding the point.

${ }^{27}$ Ibrahim Sulaiman, "Sidi Mukhtar al-Kunti", in Revolution in History: The Jihad of Usman Dan Fodio (London: Mansell Publishing Limited, 1986), p. 3. 


\section{Mukhtar Umar Bunza}

of the Hausa Sultans against the Shehu and his followers. Indeed, a decree was issued against him which forced him to go on Hijrah-Flight- from his town of Degel to the border town of Gudu in the Gobir Kingdom in February 1804. The persecution of the Hausa kings led by Sarkin Gobir Yunfa made the situation unbearable and forces were mobilized for total extermination of the Shehu and his followers, which was repelled vehemently at a battle of Tafkin Kwatto in June $1804 .^{28}$

The success recorded at this encounter by the Shehu and his disciples against the powerful coalition of the Hausa rulers boosted their morale and stamina to push for the removal of all the kings of Hausaland, which they succeeded in accomplishing in the four years from 1804-1808. Their sweeping and decisive victory was unexpected and unthinkable in the period in Nigerian areas. One factor in their remarkable victory was the role played by the network of ulama who represented the Shehu and his call to all the crannies and corners of Hausaland. They were termed the flag bearers of the Jihad movement. Each of these flag bearers was the most renowned scholar and Alim in his region.

By extension, when Muslim scholars came to the Shaikh from other parts of Hausaland, they were sent home and given authority to lead a local campaign-jihad-with a flag blessed by the Shaikh. Some of the major flag bearers receiving the blessing of the Shehu included: Moyijo to Kebbi Kingdom, Shaikh Abu Hamid, Zamfara, Mallam Umar Dallaji, Katsina, Malam Ishaq to Daura, Malam Musa, Zaria (Zazzau), Malam Sulaimanto Kano, Malam Ibrahim Zaki to Katagun, Shaikh Bi Abdur and his brother Dagimsato (the State of Hadejia), Malam Lerlima to Marmar (Borno), Malam Muhammad Manga, Misau, Malam Muhammad Wabi,Jama’are, BubaYero to Gombe, Malam Yaqub, Bauchi, Modibbo, (meaning learned in Fulfulde) Adama, Adamawa, and Shaikh Muhammad al-Hajj al-Ameen to Bagirmi, Malam Dendo, Nupeland, and Shaikh Alimi, Ilorin. ${ }^{29}$

These individuals given the authority to represent the movement in their respective states and regions were highly respected as notable scholars. Indeed, no-one among the followers of Shehu in a given geographical region was known to be clearly more knowledgeable and committed to the mission of the jihad than the one given the flag in the area. Gwoni Mukhtar as his name implies means was learned

${ }^{28}$ See Tasyin al-Waraqāt of Malam Adbullahi Fodiyo and Infäq al-Maisurfi Tärìkh biad al-Tekrur of Sultan Muhammad Bello for details.

29 See D. M. Last, Sakoto in the Nineteenth Century with Special Refrence to the Vizierate, Ph.D Thesis, (Nigeria: University of Ibadan, 1964), p. 111. 
and a jurist, Ibrahim Zaki was known with an epithet Faqih, Adamu, Sulaimanu nick-named faqih al-Adil- the learned and just, and Musa alA'lim-knowledgeable, as well as other flag bearers were noted for their learning and intellectual capability. ${ }^{30}$

They jointly succeeded in ousting the kings of their areas and were conferred with the title of 'Emir' for their states by Shehu Usmanu Danfodiyo, while the title of Amir al-Munineen, leader of the 'Faithful', was conferred on him by his disciples at the central government in Sokoto. The terms Amir and Emir are still used for the ulama who played an active role in the revolution as well as those who succeeded them in the same capacity; on the other hand, Amir al-Mumineen, Caliph or Sultan are alternatively used for those who succeeded the role of the Shehu at the Center of the Caliphate in Sokoto. ${ }^{31}$

Therefore, between 1808 and 1812 when the Caliphate was divided into two - Western and Eastern - parts by the Shehu for administrative convenience, the ulama replaced the traditional political class in leadership and governance in the areas of the Sokoto Caliphate until the British occupation in 1903. During their reign they tried in theory and practice to exemplify Islamic justice and the welfare state, and this has remained a point of reference to date in spite of the British blackmail to justify their invasion. ${ }^{32}$

\section{The British Conquest and Removal of Ulama in State Affairs in Nigeria}

British imperial ambition against the Sokoto Caliphate started only seven years after the death of its founder Shehu Usmanu in 1824. Sultan Muhammad Bello, the successor of the Shehu received presents and diplomatic gifts from King Edward VII of England through his envoy Hugh Clapperton. Thereafter, other British explorers such as Dr Henrich Barth and other European traders, missionaries and consuls followed with the main aim of conquering the Muslim land of Sokoto

${ }^{30}$ Ibid., pp. 112-4.

31 Sulaiman, Revolution in History.

${ }^{32}$ Mukhtar Umar Bunza, "Initiative for Quality Leadership and Sustainable Development: A Model from an African Islamic Polity", Proceeding World Congress on Islamic Systems 2011 (World-ISLAM2011) (Malaysia: Eduxplore Sdn, 28 Nov 2011), pp. 1-6; Mukhtar Umar Bunza, "The Application of Islamic Law and the Legacies of Good Governance in the Sokoto Caliphate, Nigeria (1804-1903): Lessons for the Contemporary Period", Electronic Journal of Islamic and Middle Eastern Law, vol. 1 (2013), pp. 84-101. 
Caliphate for the British Crown. They accomplished this through the military invasion of the Caliphate, which started in 1897 with the conquest of southern Emirates such as Ilorin, Bida and others and ended in 1903 with the conquest of Kano and Sokoto respectively.

Upon the military subjugation of the Caliphate, a new political landscape was launched which systematically replaced the reign of scholars and influence of the Muslim learned class versatile in all branches of knowledge, with those who were literate in Western education, and less scholarly in Islamic knowledge and ethics. Announcing the dawn of a new era Lord Lugard, the British High Commissioner and Commanding Officer who led the conquest of the Caliphate announced that:

...every Sultan and Emir and the principal officers of State will be appointed by the High Commissioner, throughout all this country. The High Commissioner will be guided by the usual laws of succession and the wishes of the people and chiefs, but will set them aside if he desires for good cause to do so. The emirs and chiefs who are appointed will rule over the people as of old times and take such taxes as are approved by the High Commissioner, but they will obey the laws of the Governor and will act in accordance with the advice of the Resident... (emphasis mine). ${ }^{33}$

The new criterion for employment in the administration of the new colonial government was education in the new education system brought by the British. Students who went to Al-Azhar University and similar institutions were denied opportunity to work in the colonial government, and several measures were adopted to silence the Ulama and render them ineffective and marginal in the day-to-day affairs of the state. Finally, in 1960 the British handed over political power and control to a new crop of politicians, i. e. secular political elites, and their legacy has continued to thrive ever since. ${ }^{34}$

The same administrative plans and programs continued and a number of reforms were institutionalized by the British which ensured the Muslim areas of the Caliphate adopted, in all its administrative and judicial ethos, the legacies of the British system, which sidelined the

${ }^{33}$ For the text of Lugard's speech at Sakoto on the occasion on $21^{\text {st }}$ March 1903, see Annual Report, no. 409, Nothern Nigeria, 1990).

${ }^{34}$ Mukhtar Umar Bunza, "Political Islam under British Colonial Administration in Sokoto Province: 1903 - 1950s”, Journal for Islamic Studies, vol. 22, no. 1 (2002), pp. 66-81; A.M. Yakubu, Emirs and Politicians: Reform, Reactions and Recrimination in Northern Nigeria, 1950 -1966 (Kaduna: Baraka Publishers, 2006); Michael Crowder and Obaro Ikime (eds.), West African Chiefs: Their Changing Status Under Colonial Rule and Independence (New York: Africana Publishing, 1970). 
Ulama and the Jurist Qadis in favor of western educated lawyers in the adjudication of justice. The new teachers and administrators were London-based or trained in English schools established to feed the needs of the colonial administration, such as at Katsina College and the Sokoto Provincial School; thus providing a viable platform for the growth and development of Western civilization..$^{35}$

The same administrative pattern continued until 1999 when the fourth republic heralded a new dawn in the revitalization of Islamic culture and tradition, opening a new chapter in almost all arms of governance for the relevance of the Ulama.

\section{The Democratic Dispensation of 1999 and the Relevance of the Ulama in Contemporary Nigeria}

After decades of military rule, from 1983 to 1999 a new epoch of freedom and political expression was opened for the diverse people of Nigeria of different historical and religious orientations to express their views and opinions and redefine their political futures in line with their yearnings and aspirations. It was that new experience that according to Rotimi Suberu brought the reintroduction of Shari'ah to extend to criminal cases, a move in conflict with what the British had approved during the colonial administration, and after independence. ${ }^{36}$

Barely three days after inauguration to office, in August 1999 the Executive Governor of Zamfara State announced the extension of the limits of Shari'ah to criminal cases, and established commissions and agencies which were Islamic in nature, such as Hisbah, the Qur'anic Memorization Commission, Masjid affairs, and above all, a new Ministry for Religious Affairs. This move by the Zamfara Governor led state governors in ten other states in northern Nigeria to make similar declarations between the years 2000-2002; thus, the number of states upholding the Shari'ah rose to eleven states. The Shari'ah and the body of Islamic systems, it was argued, had been part and parcel of the political evolution and development of Nigeria, and were therefore not something

35 Andrew E. Barnes, Making Headway: The Introduction of Western Civilization in Colonial Northern Nigeria (Rochester: University of Rochester Press, 2009).

${ }^{36}$ A.E. Banes, "Continuity and Change in Nigeria's Sharia Debate", in L'Islam Politique an sud du Sahara: Identitiés, discours et enjeux, ed. by M. Gomes-Perez (Paris: Karthala, 2005), pp. 290-96. 
new. ${ }^{37}$ The level of commitment and application of Shari'ah, however, varied from state to state based on the magnitude of the challenges in the process of implementation within and outside the state.

The action taken as stressed by these Governors was to satisfy the demand of the electorates who voted them into office, and provided constitutional rights for Muslims to practice their religious tenets. There were great waves of support and criticism within Nigeria and the so-called international community who viewed the decision as a reversal of the colonial legacies, and triumph of the ousted Islamic system. ${ }^{38}$

It was the introduction of Islamic based institutions that needed the services of learned Islamic officers to fill the gaps and to use their knowledge in the discharge of the assignments. In all these states Council of Ulama were established and played the role of an advisory body to government on a range of issues including security and co-existence. There are also the Directorate of Religious Affairs, the Ministry for Religious Affairs, or the Special Adviser on Religious Matters to which staff are drawn largely from the learned scholars / Ulama who have the intellectual and scholarly capability to advise and guide appropriately.

Philip Ostein identified the emergence of new Shariah compliant programs and government parastatals which made the demand for the ulama and their roles imperative in all the eleven shariah states in Nigeria. ${ }^{39}$

- Shariah Commission (most States).

- Council of Ulama (All shariah states, membership from all sects and organizations).

- Ministry for Religious Affairs (in major shariah States such as Zamfara, Kano, and Sokoto, full scale ministry with structures and hierarchy: Commissioner, Permanent Secretary, Directors and others, with full budgetary allocation).

- Special Adviser on Religious Matters (especially in states where a ministry for Religious Affairs was not yet established).

- Shariah Research and Development Board (I think only for

${ }^{37}$ Mukhtar Umar Bunza, "Shari'ah in the History and Political Development of Nigeria", in Religion in Politics: Secularism and National Integration in Modern Nigeria, ed. by Julius O. Adekunle (New York: Africa World Press, 2009), pp. 137-158.

${ }^{38}$ Ibrahim Ado-Kurawa, Shari'ah and the Press in Nigeria: Islam versus Western Christian Civilization (Nigeria: Kurawa Holdings Limited, 2001). The author compiled a number press statements expressing views and opinions of mostly critiques of the shari'ah.

39 Philip A. Ostien, Sharia Implementation in Northern Nigeria 1999-2006, vol. VI (Nigeria: Spectrum Books Limited, 2007), pp. 1-127. 
Zamfara State, with the aim of investigating and finding solutions to the challenges faced in shariah implementation and internally and externally).

- Commission for Qur'anic Recitation and Memorization (Notably for Zamfara, Sokoto, and Kano, in other states. Qur'anic Recitation Competition Committee to organize for participation of the States representatives in the annual contest, with final session at Mecca, Saudi Arabia).

- Zakat and Endowment Board (for all shariah states, with responsibility for collection and disbursement of Zakat and Waqf from the wealthy to the needy).

- Commission for the Destitute and Less Privileged (available in Sokoto and Zamfara, oversee the health and shelter needs of the destitute in the states by settling medical bills, repairing and rehabilitating the houses of the needy, funding through government and Zakat funds).

- Rehabilitation Committee (available in Sokoto State, for rehabilitation of the mentally ill in psychiatric hospitals, training of youth and handicapped in crafts and trades).

- Mosque (Masjid) Committee (for the general cleanliness and rehabilitation of mosques, available in Zamfara state).

- Moon Sighting Committee (the Committee supports the Emirates and the Sultanate Council in Sokoto with relevant information about moon sighting especially for Ramadan and other Muslims festivities, only in Zamfara State)

- Hisbah Commission (in almost all shariah states, helps the security agencies and the police to arrest criminals in the states).

- Ramadan Iftar Committee (very popular in Sokoto, Zamfara and Kano, with a budgetary allocation of about N100, 000, 000 (one hundred million Naira, almost $\$ 600,000)$. to provide food for a number of Iftar centers during the Ramadan period). A radical Imam, Sheikh Abubakar Jibril, of the famous Farfaru Jumu'at mosque served as pioneer Chairman of the Committee in Sokoto State).

- Public Complaint Commission (in Zamfara State, an agency that investigates the miscarriage of justice especially in government ministries and agencies and monitors cases especially involving strong and weak claimants).

- Adaidata Sahu (initiated by Governor Shekarau of Kano State to enforce: public morality; censorship of the media; segregation of the sexes on public transport; and, to enhance the activities of the 
Hisbah, only in Kano State).

Membership as well as the Chairmanship of most of the above committees, Boards and Commissions is largely drawn from among the well-known activist scholars-Ulama, and is in some cases assisted and supported by mainstream administrators in the respective ministries and parastatals. In Zamfara State, the first Commissioner for the Ministry of Religious Affairs, Sheikh Muhammad Wakkala, was an Islamic scholar trained in the Sudan. He served in that capacity for eight years, and has been the Deputy Governor since the 2011 elections. A renowned Islamic preacher under the Izala Sheikh Muhammad Tukur Jangebe was the Commissioner in the Zamfara Ministry for Religious Affairs after Wakkala and during the time of Governor Aliyu Shinkafi of the PDP. Dr. Atiku Balarabe, a Tijjani Sheikh, has served as Director General of the Hisbah Commission since 2004.

In Kano, the new window of opportunity brought a number of classes of Ulama, such as Sheikh Umar Ibrahim Kabo, an Azhar trained cleric who served as Chairman of the Kano Council of Ulama, Professor Sani Zaharadden who served as Chairman of the Zakat and Hubusi Committee, and is currently a renowned Islamic preacher, Sheikh Ibrahim Daurawa, who was appointed by the present administration of Kano State to serve as Director of the Hisbah Board. ${ }^{40}$

A similar scenario can be found in other states that recognize shariah as their legal code. In addition to serving in various capacities as paid government officials, the Ulama also enjoyed the power of sensitizing and mobilizing the electorate to vote for a certain candidate. The affinity of the Ulama with the masses, together with the growing religious fervor among the youth in the country, have added to their advantage and influence. Scholars like Shekh Jaafar Adam and Sheihk Rijiyar Lemo presented a series of lectures to thousands of audiences on the qualities to look for in a candidate during the elections. ${ }^{41}$ That was clearly seen during the 2011 elections where Ulama took the campaign north and south throughout the country to ensure Muslims were able to exercise their civic rights. They were encouraged not to vote for the

40 Saheed Ahmad Rufai, "The Mosque and the State House: Political Islam in Contemporary Nigeria since 1999", World Journal of Islamic History and Civilization, vol. 1, no. 3 (2011), pp. 178-186.

${ }^{41}$ Haruna Wakili, "Islam and the Political Arena in Nigeria: The Ulama and the 2007 Elections", ISITA Working Paper Series, no. 09-004 (Illinois: Northwestern University, 2009), pp. 1-10. 
non-Muslim candidate in the presidential elections, not only on the basis of religious difference but also due to the failure to address the needs of Muslims by the current government. ${ }^{42}$

Muhammad Nuruddeen concludes that the role of the Ulama is essential as a tool for social change. As he states:

Muslim scholars, the Ulama, are said to determine how Muslims understand Islam and the world. A study by the John Hopkins Bloomberg School of Public Health (JHB), using an "Ulama intervention model" affirms that religious leaders in the Muslim world play a decisive role in determining their community's beliefs and attitudes. The model essentially involved selecting and sensitizing the Ulama in Pakistan, as communicators and educators who influence public opinion, in realizing development goals in a project on maternal, newborn and child health. The Ulama employed Friday sermons (wa'a) as one of the instruments for Behaviour Change Communication (BCC) with positively encouraging outcomes that made the study to state, "The present report describes, in length and with impact evidence, the Ulama intervention as a model that can be replicated for other development causes and in countries with a sizeable Muslim population". 43

The government employs the service of the Ulama to sell its programs to the public especially on issues like Polio Immunization, HIV-AIDS campaigns, voter mobilization, and even traffic regulation sensitization etc. This further confirms the growing roles and relevance of the Ulama not only in serving in government but in ensuring the success, acceptability or otherwise of the government, its programs and projects.

\section{E. Concluding Remarks}

This paper shows the restoration and increasing rejuvenation of the powers and influence of the Muslim scholars-Ulama, especially since the return to democracy after almost two decades of military dictatorship in Nigeria. The focus has been those Muslim majority states which reintroduced the shariah legal code after over a century of suspension. By tracing the historical role of Muslim scholars and their responsibilities as enshrined for them by Islam, this paper offers a brief survey of various

${ }^{42}$ A special committee under the Izala was charged with the resposibility under the leadership of Shaikh Kabir Gombe. Audio cassettes in possession of the author.

${ }^{43}$ Ibrahim Nuruddeen Muhammad, "Waqf, Values and the Ulama: Towards Harnessing Philanthropy for Community Uplift in Northern Nigeria", SSRN Scholarly Paper, no. ID 2253994 (New York: Social Science Research Network, 2013). 
Muslim societies to provide a foundation for the articulation of and understanding of the phenomenon. In the Nigerian Muslim experience, the Ulama class ascended to power through a Jihad in 1804 led by Shehu Usmanu Danfodiyo, and successfully completed by $1809 / 1810$. The capital of the Caliphate was founded at Sokoto at that time. After almost a century, the British led military aggression ousted the Muslim scholars and replaced them with new elites trained by Europeans to be in-charge and control state affairs, the Ulama were completely marginalized from 1900-1999 as the system in operation did not favor their participation. The new millennium opened fresh opportunities for the ousted ulama through the creation and establishment of state level offices that needed highly educated jurists and Islamists. The declaration of shariah and its accompanying agencies in the Muslim dominated states in northern Nigeria created new jobs, new opportunities, and new statuses for learned scholars. This study has shown that increasing religiosity and trust in the ulama by the masses in the context of widespread disillusionment with the political class, who are mostly viewed as corrupt opportunists, has opened yet another horizon for the ulama in the political future of Nigeria. 
The New Role of Ulama in Nigeria BIBLIOGRAPHY

Abba, Yusufu, “The 1804 Jihad in Hausaland as a Revolution”, in Studies in the History of the Sokoto Caliphate: The Sokoto Seminar Papers, ed. by Yusufu Bala Usman, Nigeria: Dept. of History, Ahmadu Bello University, 1979.

Ado-Kurawa, Ibrahim, Shari'ah and the Press in Nigeria: Islam versus Western Christian Civilization, Nigeria: Kurawa Holdings Limited, 2001.

Andrew E. Barnes, Making Headway: The Introduction of Western Civilization in Colonial Northern Nigeria, Rochester, NY: University of Rochester Press, 2009.

Azra, Azyumardi, Islam in the Indonesian World: An Account of Institutional Formation, Jakarta: Mizan Pustaka, 2006.

Banes, A.E., "Continuity and Change in Nigeria's Sharia Debate", in L'Islam Politique au sud du Sahara: Identitiés, discours et enjeux, ed. by M. Gomes-Perez, Paris: Karthala, 2005, pp. 209-26.

Brinton, Jacquelene, "Preaching and the Epistemological Enforcement of 'Ulamā' Authority: the Sermons of Muhammad Mitwallī Sha'rāwì̀', Intellectual Discourse, vol. 19, no. 1, 2011, pp. 91-121.

Bunza, Mukhtar Umar, "Political Islam Under British Colonial Administration In Sokoto Province: 1903 - 1950s", Journal for Islamic Studies, vol. 22, no. 1, 2002 [http://dx.doi.org/10.4314/jis. v22i1.48386].

----, "Shari'ah in the History and Political Development of Nigeria", in Religion in Politics: Secularism and National Integration in Modern Nigeria, ed. by Julius O. Adekunle, New York: Africa World Press, 2009.

----, "Migration and Itinerancy among the Ulama'a in West Africa: The Making of Trans-National Muslim Intelligentsia in Nigeria", in Religion et Migration, ed. by E. Ross, F. Harrak \& S. Anegay, Rabbat: Institute des Etudes Africaines, 2012, pp. 65-80.

----, "The Application of Islamic Law and the Legacies of Good Governance in the Sokoto Caliphate, Nigeria (1804-1903): Lessons for the Contemporary Period", Electronic Journal of Islamic and Middle Eastern Law, vol. 1, 2013, pp. 84-101.

----, "Initiative for Quality Leadership and Sustainable Development: A Model From an African Islamic Polity", Proceeding World Congress on Islamic Systems 2011 (World-ISLAM2011), Malaysia: Eduxplore Sdn, Al-Jāmi'ah, Vol. 52, No. 2, 2014 M/1435 H 
28 Nov 2011.

Burke, Jeffrey Charles, "The Role of Ulama' during the French Rule of Egypt, 1798-1801”, Ph.D. Thesis, Canada: McGill University, 1992. Crecelius, Daniel, "Non-ideological Response of the Egyptian Ulama' to Modernization", in Scholars, Saints, and Sufis: Muslim Religious Institutions in the Middle East since 1500, ed. by Nikki R. Keddie, Los Angeles: University of California Press, 1972.

Crowder, Michael and Obaro Ikime (eds.), West African Chiefs: Their Changing Status Under Colonial Rule and Independence, New York: Africana Publishing, 1970.

Danfodiyo, Shehu Usmanu, Kitab al-Farq, trans. by Mervyn Hiskett, Sokoto: Bi-Centernary, 2004.

Fodio, Shehu Usman Dan, Najm al-Ikhwān Yabtadūna Biḩibbi Idhnillāh fi Umür al-Zamān, Cairo.

Haddad, Yvonne Yazbeck, "Muhammad Abduh: Pioneer of Islamic Reform", in Pioneers of Islamic Revival, ed. by Alī Rāhnamā, London: Zed Books, 1994.

Hunter, Shireen T. (ed.), Reformists Voices of Islam: Mediating Islam and Modernity, New York: M.E. Sharpe, 2009.

Imam Khomeini, "Ijtihad and the Role of Ulama", Crescent Magazine, International Newsmagazine of the Islamic Movement, 29/7, http:/ / www. crescent-online.net/2009/08/imam-khomeini-ijtihad-and-the-roleof-ulama-1649-articles.html.

Ismail, M., Ulama Silam dalam Kenangan, Malaysia: Bangi University, 1993. Kadir, Nor Adina Abdul and Mohd Roslan Mohd Nor, "The Role of Ulama in Reconstructing of Religious Education in Malaysia during Early 20th Century", Middle-East Journal of Scientific Research, vol. 11, no. 9, 2012, pp. 1257-65 [http://dx.doi.org/10.5829/idosi. mejsr.2012.11.09.22705].

Marsot, Afaf Lutfi al-Sayyid, "The Role of the 'Ulama' in Egypt, Early Nineteenth Century", in Political and Social Change in Modern Egypt, ed. by P.M. Holt, Oxford: Oxford University Press, 1968.

Muhammad, Ibrahim Nuruddeen, "Waqf, Values and the Ulama: Towards Harnessing Philanthropy for Community Uplift in Northern Nigeria”, SSRN Scholarly Paper, no. ID 2253994, New York: Social Science Research Network, 2013. 
The New Role of Ulama in Nigeria

Noor, Farish A., Yoginder Sikand, and Martin van Bruinessen (eds.), The Madrasa in Asia: Political Activism and Transnational Linkages, Amsterdam: Amsterdam University Press, 2009.

Ostien, Philip A., Sharia Implementation in Northern Nigeria 1999-2006, vol. VI, Nigeria: Spectrum Books Limited, 2007.

Qureshi, Jawad, The Discourses of the Damascene Sunni Ulama During the 2011 Revolution, Scotland: University of St. Andrews Centre for Syrian Studies, 2012.

Rahemtulla, Shadaab, "Conceptualizing the Contemporary Ulama alAzhar, Lay Islam, and Egyptian State in the late 20th Century", M.A. Thesis, Canada: Simon Fraser University, 2007.

Rufai, Saheed Ahmad, "The Mosque and the State House: Political Islam in Contemporary Nigeria since 1999”, World Journal of Islamic History and Civilization, vol. 1, no. 3, 2011, pp. 178-86.

Saby, Yusny, Islam and Social Change: The Role of the Ulama in Acehnese Society, Malaysia: Universiti Kebangsaan Malaysia, 2005.

Steiner, Kerstin, "Madrasah in Singapore: Tradition and Modernity in Religious Education", SSRN Scholarly Paper, no. ID 2342393, New York: Social Science Research Network, 2011.

Sulaiman, Ibrahim, "Sidi Mukhtar al-Kunti", in Revolution in History: The Jihad of Usman Dan Fodio, London: Mansell Publishing, 1986.

Waardenburg, Jean Jacques, Islam: Historical, Social, and Political Perspectives, Berlin: Walter De Gruyter, 2002.

Wakili, Haruna, "Islam and the Political Arena in Nigeria: The Ulama and the 2007 Elections", ISITA Working Paper Series, no. 09-004, Illinois: Northwestern University, 2009.

Yakubu, A.M., Emirs and Politicians: Reform, Reactions and Recrimination in Northern Nigeria, 1950 -1966, Kaduna: Baraka Publishers, 2006.

Zaman, Muhammad Qasim, The Ulama in Contemporary Islam: Custodians of Change, New York: Princeton University Press, 2007.

Zulkifli, "The Ulama, Religious Authority and Recognition in Indonesia”, presented at the Annual Conference on Islamic Studies X, Banjarmasin, 1 Nov 2010. 